\title{
A Call for Conducting Multivariate Mixed Analyses
}

\author{
Anthony J. Onwuegbuzie (Corresponding author) \\ Department of Educational Leadership, Box 2119 \\ Sam Houston State University, Huntsville, Texas 77341-2119, USA \\ E-mail: tonyonwuegbuzie@aol.com
}

Received: April 13, 2016 Accepted: May 25, 2016 Published: June 9, 2016

doi:10.5296/jei.v2i2.9316 URL: http://dx.doi.org/10.5296/jei.v2i2.9316

\begin{abstract}
Several authors have written methodological works that provide an introductory- and/or intermediate-level guide to conducting mixed analyses. Although these works have been useful for beginning and emergent mixed researchers, with very few exceptions, works are lacking that describe and illustrate advanced-level mixed analysis approaches. Thus, the purpose of this article is to introduce the concept of multivariate mixed analyses, which represents a complex form of advanced mixed analyses. These analyses characterize a class of mixed analyses wherein at least one of the quantitative analyses and at least one of the qualitative analyses both involve the simultaneous analysis of multiple variables. The notion of multivariate mixed analyses previously has not been discussed in the literature, illustrating the significance and innovation of the article.
\end{abstract}

Keywords: Mixed methods data analysis, Mixed analysis, Mixed analyses, Advanced mixed analyses, Multivariate mixed analyses

\section{Crossover Nature of Mixed Analyses}

At least 13 decision criteria are available to researchers during the data analysis stage of mixed research studies (Onwuegbuzie \& Combs, 2010). Of these criteria, the criterion that is the most underdeveloped is the crossover nature of mixed analyses. Yet, this form of mixed analysis represents a pivotal decision because it determines the level of integration and complexity of quantitative and qualitative analyses in mixed research studies. Broadly speaking, the crossover nature of mixed analyses is represented by an interactive continuum whereby non-crossover mixed analyses and crossover mixed analyses lie at the opposite ends of the continuum.

\subsection{Non-Crossover Mixed Analyses}

As described by Onwuegbuzie and Combs (2010), non-crossover mixed analyses, 
representing the least integrated way of mixing and combining qualitative and quantitative analyses, involve (a) the collection of both qualitative and quantitative data and (b) the qualitative analysis of qualitative data and quantitative analysis of quantitative data (i.e., within-tradition analysis). Although non-crossover mixed analyses are not as complex as are crossover mixed analyses, they are much more complex to conduct than are analyses conducted in monomethod studies (i.e., qualitative analysis of qualitative data only $O R$ quantitative analysis of quantitative data only). Indeed, a mixed research study wherein a non-crossover mixed analysis is conducted might involve any one of the 58 classes of quantitative data analysis approaches identified by Onwuegbuzie, Leech, and Collins (2011) (cf. Figure 1) combined with any of the identified 34 qualitative data analysis approaches identified by Onwuegbuzie and Denham (2014) (cf. Table 1), any of Miles and Huberman's (1994) 19 within-case analysis methods (cf. Table 2), any of Miles and Huberman's (1994) 18 cross-case analysis methods (cf. Table 3), any of Saldaňa's (2012) 32 coding techniques (cf. Table 4), or the like.

\begin{tabular}{|c|c|}
\hline \multicolumn{2}{|r|}{ Measurement Techniques } \\
\hline Name of Analytical Technique & Description \\
\hline Classical Test Theory & $\begin{array}{l}\text { Analyzes the relationship among observed scores, true scores, and error in an } \\
\text { attempt to predict outcomes of psychological and behavioral measurement }\end{array}$ \\
\hline $\begin{array}{l}\text { Item Response Theory } \\
\text { (Latent Trait Theory, Strong True Score } \\
\text { Theory, Modern Mental Test Theory) }\end{array}$ & $\begin{array}{l}\text { Analyzes the probabilistic relationship between the response that a person } \\
\text { provides (e.g.. examinee) on a quantitative item(s) and item parameters (e.g., } \\
\text { item difficulty, item discrimination, guessing parameter) and person } \\
\text { parameters/latent traits (e.g., ability, personality trait) }\end{array}$ \\
\hline Multilevel Item Response Theory & $\begin{array}{l}\text { Estimates latent traits of the respondent at different levels and examines the } \\
\text { relationships between predictor variables and latent traits at different levels }\end{array}$ \\
\hline Exploratory Factor Analysis & $\begin{array}{l}\text { Explores the underlying structure of correlations among observed variables in } \\
\text { an attempt to reduce dimensionality of data, wherein a small(er) number of } \\
\text { factors significantly account for the correlations among the set of measured } \\
\text { variables; utilizes estimates of common variance or reliability on the main } \\
\text { diagonal of the correlation matrix that is factor analyzed }\end{array}$ \\
\hline Principal Component Analysis & $\begin{array}{l}\text { Explores the underlying structure of correlations among observed variables in } \\
\text { an attempt to reduce dimensionality of data, wherein a small(er) number of } \\
\text { factors significantly account for the correlations among the set of measured } \\
\text { variables; utilizes the total variance of each variable to assess the shared } \\
\text { variation among the variables. That is, it uses "ones" on the diagonal of the } \\
\text { correlation matrix that is factor analyzed. Principal component analysis } \\
\text { typically is conducted for variable reduction because it can be used to develop }\end{array}$ \\
\hline
\end{tabular}




\begin{tabular}{|c|c|}
\hline & $\begin{array}{l}\text { scores that are combinations of observed variables, whereas exploratory factor } \\
\text { analysis is more appropriate for exploring latent constructs and allows for } \\
\text { error in estimation models. }\end{array}$ \\
\hline Confirmatory Factor Analysis & $\begin{array}{l}\text { Verifies the factor structure of a set of observed variables; it allows testing of } \\
\text { the hypothesis that a relationship between observed variables and their } \\
\text { underlying latent constructs exists }\end{array}$ \\
\hline $\begin{array}{l}\text { Multiple Factor Analysis } \\
\text { (optimal scaling, dual scaling, } \\
\text { homogeneity analysis, scalogram } \\
\text { analysis) }\end{array}$ & $\begin{array}{l}\text { Analyzes observations described by two or more sets of variables, and } \\
\text { examines the common structures present in some or all of these set }\end{array}$ \\
\hline Hierarchical Factor Analysis & Differentiates higher-order factors from a set of correlated lower-order factors \\
\hline \multicolumn{2}{|c|}{ Assessing One Variable/Participant at a Time } \\
\hline $\begin{array}{l}\text { Descriptive Analyses } \\
\text { (i.e., measures of central tendency, } \\
\text { variation/dispersion, position/relative } \\
\text { standing, and distributional shape) }\end{array}$ & $\begin{array}{l}\text { Summarizes and describes a set of data one variable at a time in quantitative } \\
\text { terms }\end{array}$ \\
\hline Single-Subject Analysis & $\begin{array}{l}\text { Analyzes observations from one or more individuals in which each individual } \\
\text { serves as her/his own control (i.e., individual participant is the unit of } \\
\text { analysis, although a group such as a classroom also can be the analytic unit); } \\
\text { note that it is possible to include several variables at once in a design but } \\
\text { analyses typically focus on one variable at a time }\end{array}$ \\
\hline \multicolumn{2}{|c|}{ Assessing Differences through Variance Analysis } \\
\hline Independent samples $t$ test & Examines the difference between the means of two independent groups \\
\hline $\begin{array}{l}\text { Dependent samples } t \text { test } \\
\text { (paired samples } t \text { test) }\end{array}$ & $\begin{array}{l}\text { Examines the difference between the means of two groups, wherein the scores } \\
\text { in one group is paired or dependent on the scores in the other group }\end{array}$ \\
\hline Analysis of Variance (ANOVA) & $\begin{array}{l}\text { Partitions the observed variance into components based on different sources } \\
\text { of variation; one-way ANOVA examines the equality of several independent } \\
\text { groups based on one dependent/outcome variable; factorial ANOVA examines } \\
\text { the effects of two or more independent/explanatory/predictor variables and } \\
\text { their interactions }\end{array}$ \\
\hline Analysis of Covariance (ANCOVA) & $\begin{array}{l}\text { Examines whether one or more factors (and their interactions) have an effect } \\
\text { or are related to the outcome variable after removing the variance associated } \\
\text { with which quantitative predictors (covariates) }\end{array}$ \\
\hline $\begin{array}{l}\text { Multivariate Analysis of Variance } \\
\text { (MANOVA) }\end{array}$ & $\begin{array}{l}\text { Examines whether one or more factors have an effect or are related to two or } \\
\text { more outcome variables }\end{array}$ \\
\hline $\begin{array}{l}\text { Multivariate Analysis of Covariance } \\
\text { (MANCOVA) }\end{array}$ & $\begin{array}{l}\text { Examines whether one or more factors (and their interactions) have an effect } \\
\text { or are related to two or more outcome variables after removing the variance } \\
\text { associated with quantitative predictors (covariates) }\end{array}$ \\
\hline
\end{tabular}




\begin{tabular}{|c|c|}
\hline $\begin{array}{l}\text { Hierarchical Linear Modeling (HLM) } \\
\text { (multilevel modeling, mixed effects } \\
\text { modeling, covariance components } \\
\text { modeling, random-coefficient } \\
\text { regression modeling) }\end{array}$ & $\begin{array}{l}\text { Analyzes variance in an outcome variable when data are in nested categories } \\
\text { (e.g., students in a class, classes within a school, schools in one school } \\
\text { district) }\end{array}$ \\
\hline $\begin{array}{l}\text { Multivariate Hierarchical Linear } \\
\text { Modeling }\end{array}$ & $\begin{array}{l}\text { Analyzes variance in multivariate dependent variables when the covariance } \\
\text { structure of the independent variables is of interest }\end{array}$ \\
\hline $\begin{array}{l}\text { Repeated Measures Analysis of } \\
\text { Variance (RMANOVA) }\end{array}$ & $\begin{array}{l}\text { Involves an analysis of variance conducted on any design wherein the } \\
\text { independent/predictor variable(s) have all been measured on the same } \\
\text { participants under multiple conditions }\end{array}$ \\
\hline $\begin{array}{l}\text { Mixed Analysis of Variance (Mixed } \\
\text { ANOVA) }\end{array}$ & $\begin{array}{l}\text { Examines differences between two or more independent groups whereby } \\
\text { repeated measures have been taken on all participants such that one factor } \\
\text { represents a between-subjects variable and the other factor represents a } \\
\text { within-subjects variable. Observations also may be nested by a unit (e.g., } \\
\text { person) where units are generally treated as a between-subject variable. }\end{array}$ \\
\hline $\begin{array}{l}\text { Repeated Measures Analysis of } \\
\text { Covariance (RMANCOVA) }\end{array}$ & $\begin{array}{l}\text { Examines whether one or more factors (and their interactions) have an effect } \\
\text { or are related to the outcome variables (i.e., repeated measures) after } \\
\text { removing the variance associated with quantitative predictors (covariates) }\end{array}$ \\
\hline \multicolumn{2}{|c|}{ Assessing Group Membership/Relationships } \\
\hline Cluster Analysis & $\begin{array}{l}\text { Assigns a set of observations, usually people, into groups or clusters wherein } \\
\text { members of the group are maximally similar }\end{array}$ \\
\hline Q Methodology & $\begin{array}{l}\text { Involves finding relationships between participants across a sample of } \\
\text { variables }\end{array}$ \\
\hline Profile Analysis & $\begin{array}{l}\text { Classifies empirically individual observations based on common } \\
\text { characteristics or attributes measured by an observed variable(s) }\end{array}$ \\
\hline Multivariate Profile Analysis & $\begin{array}{l}\text { Classifies empirically individual observations based on common } \\
\text { characteristics or attributes (i.e., multiple dependent variables) measured by } \\
\text { observed variables (i.e., multiple independent variables) }\end{array}$ \\
\hline Chi-Square Analysis & $\begin{array}{l}\text { Involves any test statistic that has a chi-square distribution but generally } \\
\text { analyzes the independence of two categorical variables via a contingency } \\
\text { table }\end{array}$ \\
\hline $\begin{array}{l}\text { Chi-Square Automatic Interaction } \\
\text { Detection (CHAID) }\end{array}$ & $\begin{array}{l}\text { Examines the relationships between a categorical dependent measure } \\
\text { (dichotomous, polytomous, ordinal) and a large set of selected predictor } \\
\text { variables that may interact themselves; it involves a series of chi-square } \\
\text { analyses (i.e., iterative, chi-square tests of independence) being conducted } \\
\text { between the dependent and predictor variables }\end{array}$ \\
\hline $\begin{array}{l}\text { Multivariate Chi-Square Automatic } \\
\text { Interaction Detection (CHAID) }\end{array}$ & $\begin{array}{l}\text { Examines the relationships between two or more categorical dependent } \\
\text { measure (dichotomous, polytomous, ordinal) and a large set of selected } \\
\text { predictor variables that may interact themselves; it involves a series of }\end{array}$ \\
\hline
\end{tabular}




\begin{tabular}{|c|c|}
\hline & $\begin{array}{l}\text { chi-square analyses (i.e., iterative, chi-square tests of independence) being } \\
\text { conducted between the multiple dependent and predictor variables }\end{array}$ \\
\hline Descriptive Discriminant Analysis & $\begin{array}{l}\text { Explains group separation (i.e., categorical dependent/outcome variable) as a } \\
\text { function of one or more continuous or binary independent variables }\end{array}$ \\
\hline Predictive Discriminant Analysis & $\begin{array}{l}\text { Predicts a group membership (i.e., categorical dependent/outcome variable) } \\
\text { by one or more continuous or binary independent variables }\end{array}$ \\
\hline \multicolumn{2}{|l|}{ Assessing Time and/or Space } \\
\hline Time Series Analysis & $\begin{array}{l}\text { Involves analyzing, using frequency-domain methods or time-domain } \\
\text { methods, an ordered sequence of observations over time, taking into account } \\
\text { the serial dependence of the observations for the purpose of modeling and } \\
\text { forecasting. }\end{array}$ \\
\hline Survival Analysis & Analyzes time-to-event data (i.e., failure time data) \\
\hline Geostatistics & Analyzes spatiotemporal (i.e., existing in both space and time) datasets \\
\hline Panel Data Analysis & $\begin{array}{l}\text { Analyzes a particular participant or group of participants within multiple sites, } \\
\text { periodically observed over a defined time frame (i.e., longitudinal analysis). }\end{array}$ \\
\hline Correspondence Analysis & $\begin{array}{l}\text { Converts data organized in a two-way table into graphical displays, with the } \\
\text { categories of the two variables serving as points; this graphical display } \\
\text { presents the relationship between the two categorical variables }\end{array}$ \\
\hline $\begin{array}{l}\text { Canonical correspondence analysis } \\
\text { (CCA) }\end{array}$ & $\begin{array}{l}\text { Relates specific variables (e.g., types of species) to variables of interest (e.g., } \\
\text { types of environments) }\end{array}$ \\
\hline Fuzzy correspondence analysis & $\begin{array}{l}\text { Similar to Correspondence Analysis, except uses "fuzzy data"- data that are } \\
\text { coded with multiple categories instead of the common " } 0 \text { " or " } 1 \text { " }\end{array}$ \\
\hline Multiple Correspondence Analysis & $\begin{array}{l}\text { Analyzes the pattern of relationships of several categorical dependent } \\
\text { variables }\end{array}$ \\
\hline Discriminant Correspondence Analysis & Categorizes observations in predefined groups using nominal variables \\
\hline Proportional Hazard Model & $\begin{array}{l}\text { Estimates the effects of different covariates influencing the times-to-failure of } \\
\text { a system (i.e., hazard rate) }\end{array}$ \\
\hline \multicolumn{2}{|c|}{ Explaining or Predicting Relationships Between Variables } \\
\hline Linear Regression & $\begin{array}{l}\text { Examines the linear correlations between one (simple regression) or more } \\
\text { (multiple regression) binary or continuous explanatory variables and a single } \\
\text { continuous dependent variable }\end{array}$ \\
\hline Non-Linear Regression & $\begin{array}{l}\text { Examines the non-linear correlations between one or more binary or } \\
\text { continuous explanatory variables and a single continuous dependent variable }\end{array}$ \\
\hline Probit regression & $\begin{array}{l}\text { Examines the non-linear correlations between one or more binary or } \\
\text { continuous explanatory variables and a binomial response variable }\end{array}$ \\
\hline
\end{tabular}




\begin{tabular}{|c|c|}
\hline Regression Discontinuity Analysis & $\begin{array}{l}\text { Examines causal effects of interventions, wherein assignment to a treatment } \\
\text { condition is determined, at least partly, by the value of an observed covariate } \\
\text { that lies on either side of a fixed threshold/cut-score }\end{array}$ \\
\hline $\begin{array}{l}\text { Logistic Regression } \\
\text { (logit regression) }\end{array}$ & $\begin{array}{l}\text { Examines the relationship between one (simple logistic regression model) or } \\
\text { more (multiple logistic regression model) binary or continuous explanatory } \\
\text { variables and a single categorical dependent variable }\end{array}$ \\
\hline Multivariate Logistic Regression & $\begin{array}{l}\text { Examines the relationship between one or more explanatory variables and two } \\
\text { or more categorical dependent variable(s) }\end{array}$ \\
\hline Descriptive Discriminant Analysis & $\begin{array}{l}\text { Explains group separation (i.e., categorical dependent/outcome variable) as a } \\
\text { function of one or more continuous or binary independent variables }\end{array}$ \\
\hline Predictive Discriminant Analysis & $\begin{array}{l}\text { Predicts a group membership (i.e., categorical dependent/outcome variable) } \\
\text { by one or more continuous or binary independent variables. }\end{array}$ \\
\hline $\begin{array}{l}\text { Log-Linear Analysis } \\
\text { (multi-way frequency analysis) }\end{array}$ & $\begin{array}{l}\text { Determines which of a set of three or more variables (and/or interactions) best } \\
\text { explains the observed frequencies with no variable serving as the } \\
\text { dependent/outcome variable }\end{array}$ \\
\hline Canonical Correlation Analysis & $\begin{array}{l}\text { Examines the multivariate relationships between two or more binary or } \\
\text { continuous predictor variables and two or more binary or continuous outcome } \\
\text { variables }\end{array}$ \\
\hline Path Analysis & $\begin{array}{l}\text { Describes and quantifies the relationship of a dependent/outcome variable to a } \\
\text { set of other variables, with each variable being hypothesized as having a } \\
\text { direct effect or indirect effect (via other variables) on the dependent variable }\end{array}$ \\
\hline $\begin{array}{l}\text { Structural Equation Modeling } \\
\text { (causal modeling, covariance structure } \\
\text { analysis) }\end{array}$ & $\begin{array}{l}\text { Involves building and testing statistical models; it encompasses aspects of } \\
\text { confirmatory factor analysis, path analysis, and regression analysis }\end{array}$ \\
\hline $\begin{array}{l}\text { Multilevel Structural Equation } \\
\text { Modeling }\end{array}$ & $\begin{array}{l}\text { Used when the units of observation form a hierarchy of nested clusters and } \\
\text { some variables of interest are measured by a set of items or fallible } \\
\text { instruments }\end{array}$ \\
\hline Multilevel latent class modeling & $\begin{array}{l}\text { Analyzes data with a multilevel structure such that model parameters are } \\
\text { allowed to differ across groups, clusters, or level- } 2 \text { units; the dependent } \\
\text { variable is not directly observed but represents a latent variable with two or } \\
\text { more observed indicators }\end{array}$ \\
\hline Correlation coefficient & Measures the association between two variables \\
\hline Multidimensional Scaling & $\begin{array}{l}\text { Explores similarities or dissimilarities in data; it displays the structure of a set } \\
\text { of objects from data that approximate the distances between pairs of the } \\
\text { objects }\end{array}$ \\
\hline Social Network Analysis & $\begin{array}{l}\text { Involves the identification and mapping of relationships and flows among } \\
\text { people, groups, institutions, web sites, and other information- and } \\
\text { knowledge-producing units of different sizes; it provides both a visual and a }\end{array}$ \\
\hline
\end{tabular}




\begin{tabular}{|l|l|}
\hline \hline Propensity Score Analysis & $\begin{array}{l}\text { mathematical analysis of complex human systems; the unit of analysis is not } \\
\text { the individual, but an element consisting of a collection of two or more } \\
\text { individuals and the linkages among them }\end{array}$ \\
\hline $\begin{array}{l}\text { Replaces multiple covariates such that just one score is applied as a predictor } \\
\text { rather than multiple individual covariates, thereby greatly simplifying the } \\
\text { model; balances the treatment and control groups on the covariates when } \\
\text { participants are grouped into strata or subclassified based on the propensity } \\
\text { score; it adjusts for differences via study design (matching) or during } \\
\text { estimation of treatment effect (stratification/regression) }\end{array}$ \\
\hline
\end{tabular}

Figure 1. Established classes of quantitative data analysis techniques and descriptions Note. ${ }^{\mathrm{a}}$ For many of these analyses, nonparametric versions and Bayesian versions exist.

Adapted from "Toward a new era for conducting mixed analyses: The role of quantitative dominant and qualitative dominant crossover mixed analyses," by A. J. Onwuegbuzie, N. L. Leech, and K. M. T. Collins, 2011, in M. Williams \& W. P. Vogt (Eds.), The Sage handbook of innovation in social research methods, pp. 354-356. Copyright 2011 by Sage Publications.

Table 1. List of formal qualitative analysis techniques identified by Onwuegbuzie and Denham (2014)

\begin{tabular}{|c|c|}
\hline Type of Analysis & Short Description of Analysis \\
\hline 1. Word Count & $\begin{array}{l}\text { Counting the total number of words used or the number of times a } \\
\text { particular word is used }\end{array}$ \\
\hline 2. Semiotics & $\begin{array}{l}\text { Using talk and text as systems of signs under the assumption that no } \\
\text { meaning can be attached to a single term }\end{array}$ \\
\hline 3. Text Mining & $\begin{array}{l}\text { Analyzing naturally occurring text in order to discover and capture } \\
\text { semantic information }\end{array}$ \\
\hline 4. Discourse Analysis & $\begin{array}{l}\text { Selecting representative or unique segments of language use, such as } \\
\text { several lines of an interview transcript, and then examining the selected } \\
\text { lines in detail for rhetorical organization, variability, accountability, } \\
\text { and positioning }\end{array}$ \\
\hline 5. Classical Content Analysis & Counting the number of codes \\
\hline 6. Schema Analysis & $\begin{array}{l}\text { Searching for cultural schemata (i.e., scripts) in texts, which include } \\
\text { identifying semantic relationships between elements of component } \\
\text { schemas }\end{array}$ \\
\hline 7. Latent Content Analysis & Uncovering underlying meaning of text \\
\hline 8. Manifest Content Analysis & $\begin{array}{l}\text { Describing observed (i.e., manifest) aspects of communication via } \\
\text { objective, systematic, and empirical means }\end{array}$ \\
\hline 9. Keywords-In-Context & Identifying keywords and utilizing the surrounding words to \\
\hline
\end{tabular}




\begin{tabular}{|c|c|}
\hline & understand the underlying meaning of the keyword \\
\hline 10. Constant Comparison Analysis & $\begin{array}{l}\text { Systematically reducing data to codes, then developing themes from } \\
\text { the codes }\end{array}$ \\
\hline $\begin{array}{l}\text { 11. Membership Categorization } \\
\text { Analysis }\end{array}$ & $\begin{array}{l}\text { Utilizing the role that interpretations play in making descriptions and } \\
\text { the consequences of selecting a particular category (e.g., baby, sister, } \\
\text { brother, mother, father = family) }\end{array}$ \\
\hline 12. Narrative Analysis & $\begin{array}{l}\text { Considering the potential of stories to give meaning to individual's } \\
\text { lives, and treating data as stories, enabling researchers to take account } \\
\text { of research participants' own evaluations }\end{array}$ \\
\hline 13.Conversation Analysis & $\begin{array}{l}\text { Utilizing the behavior of speakers to describe people's methods for } \\
\text { producing orderly social interaction }\end{array}$ \\
\hline $\begin{array}{l}\text { 14. Ethnographic Decision Models } \\
\text { (EDM) }\end{array}$ & $\begin{array}{l}\text { Building a model of the decision process for a behavior of interest, } \\
\text { resulting in a display of data, via decision trees, decision tables, or sets } \\
\text { of rules that take the form of if-then statements }\end{array}$ \\
\hline 15. Critical Discourse Analysis & $\begin{array}{l}\text { Focusing on the ways that social and political power are reproduced in } \\
\text { language; showing how power differences (e.g., gender differences) are } \\
\text { conceived, perpetuated, bolstered, and resisted }\end{array}$ \\
\hline 16. Frame/Framing Analysis & Analyzing how people understand situations and activities \\
\hline 17. Social Semiotic Analysis & $\begin{array}{l}\text { Undertakes analysis of sign and text as conditioned by social } \\
\text { organization of participants involved and by the immediate conditions } \\
\text { of their interaction emphasizing the plane of production }\end{array}$ \\
\hline 18.Domain Analysis & $\begin{array}{l}\text { Utilizing the relationships between symbols and referents to identify } \\
\text { domains }\end{array}$ \\
\hline 19. Taxonomic Analysis & $\begin{array}{l}\text { Creating a system of classification that inventories the domains into a } \\
\text { flowchart or diagram to help the researcher understand the } \\
\text { relationships among the domains }\end{array}$ \\
\hline 20. Componential Analysis & $\begin{array}{l}\text { Using matrices and/or tables to discover the differences among the } \\
\text { subcomponents of domains }\end{array}$ \\
\hline 21. Theme Analysis & $\begin{array}{l}\text { Involving identifying cognitive principles that reoccur, and uncovering } \\
\text { relationships among domains and relationships of all the various } \\
\text { components of the cultural milieu }\end{array}$ \\
\hline 22. Dialogical Narrative Analysis & $\begin{array}{l}\text { Assessment of the communicative act embedded within a precise } \\
\text { historical realization and based on the premise that every individual } \\
\text { dialogic interaction is an interaction between two specific ideological } \\
\text { horizons of which the individuals are representatives (i.e., frame of } \\
\text { historical consciousness) }\end{array}$ \\
\hline $\begin{array}{l}\text { 23. Qualitative Comparative } \\
\text { Analysis }\end{array}$ & $\begin{array}{l}\text { Systematically analyzing similarities and differences across cases, } \\
\text { typically being used as a theory-building approach, allowing the } \\
\text { analyst to make connections among previously built categories, as well } \\
\text { as to test and to develop the categories further }\end{array}$ \\
\hline 24. Multimodal Discourse Analysis & Analysis of integration of language in combination with other semiotic \\
\hline
\end{tabular}




\begin{tabular}{|c|c|}
\hline (MDA) & $\begin{array}{l}\text { resources or modes such as images, scientific symbolism, gesture, } \\
\text { architecture, music, or sound integrated across sensory modalities (e.g., } \\
\text { visual, auditory, tactile, olfactory, gustatory, kinesthetic) into } \\
\text { multimodal phenomena such as print materials, videos, websites, or } \\
\text { three-dimensional objects }\end{array}$ \\
\hline 25. Dimensional Analysis & $\begin{array}{l}\text { Natural analysis assigning general dimensions to all analyzed parts of a } \\
\text { phenomenon or situation based on the question "What all is involved } \\
\text { here" (i.e., provisional coding). Designation of all dimensions observed } \\
\text { in data builds an analytic dictionary. Further analysis leads to discovery } \\
\text { of "critical mass" of dimensions that represent emergent pathways } \\
\text { based on conditions, processes and consequences with perspective } \\
\text { controlling designation and salience for all dimensions }\end{array}$ \\
\hline 26. Framework Analysis & $\begin{array}{l}\text { Analyzing inductively to provide systematic and visible stages to the } \\
\text { analysis process, allowing for the inclusion of a priori as well as a } \\
\text { posteriori concepts, and comprising the following five key stages: (a) } \\
\text { familiarizing, (b) identifying a thematic framework, (c) indexing, (d) } \\
\text { charting, and (e) mapping and interpreting }\end{array}$ \\
\hline $\begin{array}{l}\text { 27. Qualitative Secondary Data } \\
\text { Analysis }\end{array}$ & $\begin{array}{l}\text { Analyzing non-naturalistic data or artifacts that were derived from } \\
\text { previous studies }\end{array}$ \\
\hline $\begin{array}{l}\text { 28. Interpretative Phenomenological } \\
\text { Analysis (IPA) }\end{array}$ & $\begin{array}{l}\text { Analyzing in detail how one or more persons, in a given context, make } \\
\text { sense of a given phenomenon-often representing experiences of } \\
\text { personal significance (e.g., major life event) }\end{array}$ \\
\hline 29. Consensual Qualitative Research & $\begin{array}{l}\text { Using open-ended questions in semi-structured data collection } \\
\text { techniques that facilitate the collection of consistent data across } \\
\text { individuals coupled with a more in-depth examination of individual } \\
\text { experiences; using several judges throughout the data analysis process } \\
\text { to yield multiple perspectives; using consensus to reach judgments } \\
\text { about the meaning of the data; using one auditor to check the work of } \\
\text { the team of judges and minimize the effects of groupthink; and using } \\
\text { domains, core ideas, and cross-analyses in the data analysis }\end{array}$ \\
\hline 30. Situational Analysis & $\begin{array}{l}\text { Assessing key social processes through cartographic situational } \\
\text { analyses emphasizing (a) maps of key elements of the situation, } \\
\text { variation, and difference (s), (b) maps of social worlds or arenas in } \\
\text { mesolevel discursive negotiations, and (c) maps of issues and } \\
\text { discursive axes focused around difference (s) of positionality and } \\
\text { relationality }\end{array}$ \\
\hline 31. Micro-Interlocutor Analysis & $\begin{array}{l}\text { Analyzing information stemming from one or more focus groups about } \\
\text { which participant(s) responds to each question, the order that each } \\
\text { participant responds, the characteristics of the response, the nonverbal } \\
\text { communication used, and the like }\end{array}$ \\
\hline 32. Rhetorical Analysis & $\begin{array}{l}\text { Analysis of the persuasiveness of discourses that are conventionally } \\
\text { and/or socially purposeful. It follows five classical canons of rhetoric } \\
\text { composition: (a) invention (i.e., discovering most optimal means of } \\
\text { persuasion through purposive devices of ethos, pathos, and logos), (b) }\end{array}$ \\
\hline
\end{tabular}




\begin{tabular}{|l|l|}
\hline \hline & $\begin{array}{l}\text { disposition (i.e., arrangement of arguments), (c) style, (d) memory } \\
\text { (e.g., use of mnemonic devices), and (e) delivery (e.g., body } \\
\text { movements, posture, or volume) }\end{array}$ \\
\hline 33. Systematic Data Integration & $\begin{array}{l}\text { Interweaving observation data and interview data obtained from } \\
\text { sequences of interactive situations }\end{array}$ \\
\hline $\begin{array}{l}\text { 34. Nonverbal Communication } \\
\text { Analysis }\end{array}$ & $\begin{array}{l}\text { Analyzing nonverbal communication in interviews, focus groups, and } \\
\text { observations }\end{array}$ \\
\hline
\end{tabular}

Note. Adapted from "Quantitative data analysis approaches," by A. J. Onwuegbuzie and M. A. Denham, 2014. Copyright 2014 by A. J. Onwuegbuzie and Onwuegbuzie and M. A. Denham.

Table 2. Miles and Huberman's (1994) within-case displays

\begin{tabular}{|c|c|}
\hline Type of Display & Description \\
\hline \multicolumn{2}{|l|}{ Partially Ordered: } \\
\hline Poem & Composition in verse \\
\hline Context Chart & $\begin{array}{l}\text { Networks that map in graphic form the interrelationships among } \\
\text { groups and roles that underlie the context of individual behavior }\end{array}$ \\
\hline Checklist Matrix & $\begin{array}{l}\text { Way of analyzing/displaying one major concept, variable, or domain } \\
\text { that includes several unordered components }\end{array}$ \\
\hline \multicolumn{2}{|l|}{ Time-Ordered: } \\
\hline Event Listing & $\begin{array}{l}\text { Matrix or flowchart that organizes a series of concrete events by } \\
\text { chronological time periods and sorts them into multiple categories }\end{array}$ \\
\hline Critical Incident Chart & Maps a few critical events \\
\hline Event-State Network & $\begin{array}{l}\text { Maps general states that are not as time-limited as events, and might } \\
\text { represent moderators or mediators that link specific events of interest }\end{array}$ \\
\hline Activity Record & $\begin{array}{l}\text { Displays a specific recurring activity that is limited narrowly in time } \\
\text { and space }\end{array}$ \\
\hline Decision Modeling Flowchart & $\begin{array}{l}\text { Maps thoughts, plans, and decisions made during a flow of activity that } \\
\text { is bounded by specific conditions }\end{array}$ \\
\hline Growth Gradient & $\begin{array}{l}\text { Network that maps events that are conceptualized as being linked to an } \\
\text { underlying variable that changes over time }\end{array}$ \\
\hline Time-Ordered Matrix & Maps when particular phenomena occurred \\
\hline \multicolumn{2}{|l|}{ Role-Ordered: } \\
\hline Role-Ordered Matrix & $\begin{array}{l}\text { Maps the participant's "roles" by sorting data in rows and columns that } \\
\text { have been collected from or about a set of data that reflect their views, } \\
\text { beliefs, expectations, and/or behaviors }\end{array}$ \\
\hline
\end{tabular}




\begin{tabular}{|c|c|}
\hline Role-By-Time Matrix & Maps the participant's "roles," preserving chronological order \\
\hline \multicolumn{2}{|l|}{ Conceptually Ordered: } \\
\hline Conceptually Clustered Matrix & $\begin{array}{l}\text { Text table with rows and columns arranged to cluster items that are } \\
\text { related theoretically, thematically, or empirically }\end{array}$ \\
\hline Thematic Conceptual Matrix & Reflects ordering of themes \\
\hline Folk Taxonomy & $\begin{array}{l}\text { Typically representing a hierarchical tree diagram that displays how a } \\
\text { person classifies important phenomena }\end{array}$ \\
\hline Cognitive Map & $\begin{array}{l}\text { Displays the person's representation of concepts pertaining to a } \\
\text { particular domain }\end{array}$ \\
\hline Effects Matrix & $\begin{array}{l}\text { Displays data yielding one or more outcomes in a differentiated } \\
\text { manner, focusing on the outcome/dependent variable }\end{array}$ \\
\hline Case Dynamics Matrix & $\begin{array}{l}\text { Displays a set of elements for change and traces the consequential } \\
\text { processes and outcomes for the purpose of initial explanation }\end{array}$ \\
\hline Causal Network & $\begin{array}{l}\text { Displays the most important independent and dependent variables and } \\
\text { their inter-relationships }\end{array}$ \\
\hline
\end{tabular}

Note. Adapted from Mapping Miles and Huberman's within-case and cross-case analyses onto the literature review process, by A. J. Onwuegbuzie and Rebecca K. Frels, 2014, unpublished manuscript, Sam Houston state University, Huntsville, TX, p. x. Copyright 2014 by A. J. Onwuegbuzie and Rebecca K. Frels.

Table 3. Miles and Huberman's (1994) cross-case displays

\begin{tabular}{|c|c|}
\hline Type of Display & Description \\
\hline \multicolumn{2}{|l|}{ Partially Ordered: } \\
\hline Partially Ordered Meta-Matrices & Display descriptive data for each of several cases simultaneously \\
\hline \multicolumn{2}{|l|}{ Case-Ordered: } \\
\hline $\begin{array}{l}\text { Case-Ordered Descriptive } \\
\text { Meta-Matrix }\end{array}$ & $\begin{array}{l}\text { Contains descriptive data from all cases but the cases are ordered by } \\
\text { the main variable of interest }\end{array}$ \\
\hline Two-Variable Case-Ordered Matrix & $\begin{array}{l}\text { Displays descriptive data from all cases but the cases are ordered by } \\
\text { two main variables of interest that are represented by the rows and } \\
\text { columns }\end{array}$ \\
\hline Contrast Table & $\begin{array}{l}\text { Displays a few exemplary cases wherein the variable occurs in low or } \\
\text { high form, and contrast several attributes of the basic variable }\end{array}$ \\
\hline Scatterplot & $\begin{array}{l}\text { Plot all cases on two or more axes to determine how close from each } \\
\text { other the cases are }\end{array}$ \\
\hline
\end{tabular}




\begin{tabular}{|c|c|}
\hline Case-Ordered Effects Matrix & $\begin{array}{l}\text { Sorts cases by degrees of the major cause of interest, and shows the } \\
\text { diverse effects for each case }\end{array}$ \\
\hline $\begin{array}{l}\text { Case-Ordered Predictor-Outcome } \\
\text { Matrix }\end{array}$ & $\begin{array}{l}\text { Arranges cases with respect to a main outcome variable, and provides } \\
\text { data for each case on the main antecedent variables }\end{array}$ \\
\hline $\begin{array}{l}\text { Predictor-Outcome Consequences } \\
\text { Matrix }\end{array}$ & $\begin{array}{l}\text { Links a chain of predictors to some intermediate outcome, and then } \\
\text { illustrates the consequence of that outcome }\end{array}$ \\
\hline \multicolumn{2}{|l|}{ Time-Ordered: } \\
\hline Time-Ordered Meta-Matrix & $\begin{array}{l}\text { Table in which columns are organized sequentially by time period and } \\
\text { the rows are not necessarily ordered }\end{array}$ \\
\hline Time-Ordered Scatterplot & Display similar variables in cases over two or more time periods \\
\hline Composite Sequence Analysis & $\begin{array}{l}\text { Permit extraction of typical stories that several cases share, without } \\
\text { eliminating meaningful sequences }\end{array}$ \\
\hline \multicolumn{2}{|l|}{ Conceptually Ordered: } \\
\hline Content-Analytic Summary Table & $\begin{array}{l}\text { Which allows the researcher to focus on the content of a meta-matrix } \\
\text { without reference to the underlying case }\end{array}$ \\
\hline Substructing & Permits the identification of underlying dimensions \\
\hline Decision Tree Modeling & Displays decisions and actions that are made across several cases \\
\hline Variable-By-Variable Matrix & $\begin{array}{l}\text { Table that displays two major variables in its rows and columns } \\
\text { ordered by intensity with the cell entries representing the cases }\end{array}$ \\
\hline Causal Models & $\begin{array}{l}\text { Network of variables with causal connections among them in order to } \\
\text { provide a testable set of propositions or hunches about the complete } \\
\text { network of variables and their interrelationships }\end{array}$ \\
\hline Causal Networks & $\begin{array}{l}\text { Comparative analysis of all cases using variables deemed to be the } \\
\text { most influential in explaining the outcome or criterion }\end{array}$ \\
\hline Antecedents Matrix & $\begin{array}{l}\text { Display that is ordered by the outcome variable, and displays all of the } \\
\text { variables that appear to change the outcome variable }\end{array}$ \\
\hline
\end{tabular}

Note. Adapted from Mapping Miles and Huberman's within-case and cross-case analyses onto the literature review process, by A. J. Onwuegbuzie and Rebecca K. Frels, 2014, unpublished manuscript, Sam Houston state University, Huntsville, TX, p. x. Copyright 2014 by A. J. Onwuegbuzie and Rebecca K. Frels.

Table 4. A Summary of Saldaňa's (2012) 32 coding methods

\begin{tabular}{|l|l|l|}
\hline & Coding Method & Definition \\
\hline 1 & Attribute Coding & Provide essential information about data for future reference \\
\hline 2 & Axial Coding & Develop a category by grouping/ sorting / reducing the number of \\
\hline
\end{tabular}




\begin{tabular}{|c|c|c|}
\hline & & codes generated from the first cycle of coding \\
\hline 3 & Causation Coding & $\begin{array}{l}\text { Analyze the causality by identifying causes, outcome, and links } \\
\text { between them }\end{array}$ \\
\hline 4 & Descriptive Coding & Describe the topic of data with descriptive nouns (i.e., topic coding) \\
\hline 5 & $\begin{array}{l}\text { Domain and Taxonomic } \\
\text { Coding }\end{array}$ & $\begin{array}{l}\text { Analyze the cultural knowledge participants use and organize them } \\
\text { into categories and reorganize them through further analysis into a } \\
\text { taxonomic tree diagram }\end{array}$ \\
\hline 6 & Dramaturgical Coding & $\begin{array}{l}\text { Apply dramaturgical terms to qualitative data to analyze interpersonal } \\
\text { and intrapersonal participant experiences }\end{array}$ \\
\hline 7 & Eclectic Coding & $\begin{array}{l}\text { Combine two or more similar First Cycle of coding methods } \\
\text { purposefully }\end{array}$ \\
\hline 8 & Elaborative Coding & $\begin{array}{l}\text { Develop codes to refine theoretical constructs emerged from previous } \\
\text { research or investigations }\end{array}$ \\
\hline 9 & Emotion Coding & $\begin{array}{l}\text { Apply codes accompanying emotion(s) to explore the interpersonal } \\
\text { and/or intrapersonal participants' experiences }\end{array}$ \\
\hline 10 & Evaluation Coding & $\begin{array}{l}\text { Apply non-quantitative codes (e.g., }+/- \text { ) to qualitative data for the } \\
\text { evaluative purpose }\end{array}$ \\
\hline 11 & Focused Coding & $\begin{array}{l}\text { Develop categories with significant or frequent codes that emerged } \\
\text { from In Vivo, Process, and/or Initial Coding }\end{array}$ \\
\hline 12 & Holistic Coding & $\begin{array}{l}\text { Analyze the data corpus as a whole and identify the basic themes or } \\
\text { issues in the data }\end{array}$ \\
\hline 13 & Hypothesis Coding & $\begin{array}{l}\text { Apply pre-established codes to qualitative data to examine a } \\
\text { researcher-generated hypothesis }\end{array}$ \\
\hline 14 & In Vivo Coding & $\begin{array}{l}\text { Apply the words verbatim that participants use to examine the possible } \\
\text { dimensions or ranges of categories }\end{array}$ \\
\hline 15 & Initial Coding & Apply provisional and tentative codes in the First Cycle of coding \\
\hline 16 & Longitudinal Coding & $\begin{array}{l}\text { Organize collected qualitative data across time; Categorize data into } \\
\text { matrices for further analysis and interpretation }\end{array}$ \\
\hline 17 & Magnitude Coding & $\begin{array}{l}\text { Apply supplemental or sub- codes to quantitize or qualitize the } \\
\text { phenomenon's intensity, frequency, direction, presence, or evaluative } \\
\text { content }\end{array}$ \\
\hline 18 & Motif Coding & $\begin{array}{l}\text { Apply original index codes utilized to classify the elements of folk } \\
\text { talks, myths, and legends; This method can be utilized for story-based } \\
\text { data such as journals or diaries }\end{array}$ \\
\hline 19 & Narrative Coding & $\begin{array}{l}\text { Develop codes representing participant narratives from literary } \\
\text { perspectives (e.g., storied, structured forms) }\end{array}$ \\
\hline
\end{tabular}




\begin{tabular}{|c|c|c|}
\hline 20 & $\begin{array}{l}\text { Outline of Cultural Materials } \\
\text { Coding (OCM) }\end{array}$ & $\begin{array}{l}\text { It was created as a specialized index for anthropologists and } \\
\text { archeologists; Provide coding for the categories of social life }\end{array}$ \\
\hline 21 & Pattern Coding & $\begin{array}{l}\text { Develop meta-codes that identify similarly coded data by grouping } \\
\text { them and generate major themes; Appropriate for Second Cycle coding }\end{array}$ \\
\hline 22 & Process Coding & Apply codes by using -ing words to indicate actions \\
\hline 23 & Protocol Coding & $\begin{array}{l}\text { Apply codes or categories in a previously developed system to } \\
\text { qualitative data (e.g., } \mathrm{ALCOH}=\text { alcoholism or drinking) }\end{array}$ \\
\hline 24 & Provisional Coding & $\begin{array}{l}\text { Utilize the preset codes emerged from preliminary investigations or } \\
\text { literature review and anticipated to be modified, revised, or deleted } \\
\text { during the data analysis }\end{array}$ \\
\hline 25 & Simultaneous Coding & $\begin{array}{l}\text { Apply two or more different codes to a single qualitative datum in the } \\
\text { different dimensions }\end{array}$ \\
\hline 26 & Structural Coding & $\begin{array}{l}\text { Categorize the data corpus into segments by similarities, differences, } \\
\text { relationships by using conceptual phrases }\end{array}$ \\
\hline 27 & Subcoding & $\begin{array}{l}\text { Develop sub categories in the hierarchies and taxonomies added to the } \\
\text { primary codes }\end{array}$ \\
\hline 28 & Theoretical Coding & $\begin{array}{l}\text { Develop the central category that covers all other codes and categories } \\
\text { by integrating and synthesizing them }\end{array}$ \\
\hline 29 & Values Coding & $\begin{array}{l}\text { Apply codes consisting of three elements, value, attitude, and belief to } \\
\text { examine a participant's perspectives or worldviews }\end{array}$ \\
\hline 30 & Verbal Exchange Coding & $\begin{array}{l}\text { Interpret data through the researcher's experience and reflection to } \\
\text { explore cultural practices; Extensive written reflection is preferred to } \\
\text { traditional margined coding methods }\end{array}$ \\
\hline 31 & Versus Coding & Identify phenomena in a dichotomy terms and exhibit itself as X VS. Y \\
\hline 32 & Theme, Theming the Data & $\begin{array}{l}\text { Identify codes in the form of sentences capturing the essence and } \\
\text { essentials of participant meanings }\end{array}$ \\
\hline
\end{tabular}

Note. Adapted from "Mapping Saldaňa's coding methods onto the literature review process," by A. J. Onwuegbuzie, R. K. Frels, and E. Hwang, 2016, Journal of Educational Issues, 2, pp. 136-139. Copyright 2016 by A. J. Onwuegbuzie, R. K. Frels, and E. Hwang.

\subsection{Crossover Mixed Analyses}

Contrastingly, in a crossover mixed analysis, one form of data (e.g., qualitative) collected can be analyzed utilizing techniques historically associated with the another tradition (e.g., quantitative) (Greene, 2007, 2008; Onwuegbuzie \& Teddlie, 2003; Teddlie \& Tashakkori, 2009), thereby yielding a higher level of integration of quantitative and qualitative analyses than would be the case if a mixed researcher had conducted a non-crossover mixed analysis (Onwuegbuzie \& Combs, 2010). That is, a crossover mixed analysis involves what can be 
called a between-tradition analysis. Thus, crossover analyses are not only more complex than are non-crossover mixed analyses, but also they are much more integrated, leading Teddlie and Tashakkori (2009) to declare that "We believe that this is one of the more fruitful areas for the further development of MM [mixed methods] analytical strategies” (p. 281).

\section{Qualitative Analysis and Quantitative Analysis Continua}

Both the array of qualitative analysis approaches and the array of quantitative analysis approaches can be viewed as lying on continua (Onwuegbuzie et al., 2011). Specifically, qualitative analysis approaches can be placed on a qualitative analysis continuum and quantitative analysis approaches can be placed on a quantitative analysis continuum. Each continuum is discussed in the following sections.

\subsection{Qualitative Analysis Continuum}

Figure 2 presents what Onwuegbuzie et al. (2011) referred to as the qualitative analysis continuum. In this figure, qualitative analyses are placed on the continuum based on the degree to which qualitative analytical assumptions are combined with quantitative analytical assumptions (i.e., level of integration). Thus, for example, on the left side of the continuum are approaches like word count, in which a quantitative analysis (i.e., descriptive analysis) is used to analyze qualitative data (e.g., words that are extracted from individual interviews, focus group, documents). In contrast, on the right side of the continuum are approaches like constant comparison analysis that represent purely a qualitative analysis of qualitative data. Lying between these two extremes are qualitative analyses that involve the (strong) use of both quantitative analysis (i.e., reflecting quantitative-based assumptions [i.e., postpositivist]) and qualitative analysis assumptions (i.e., reflecting qualitative-based assumptions [e.g., constructivist-based]), such as classical content analysis and qualitative comparative analysis (cf. Table 1). For example, with classical content analysis, qualitative data first are analyzed qualitatively to yield categories (e.g., sub-themes, themes, meta-themes), and then these emergent categories are subjected to a quantitative analysis - specifically, a descriptive analysis (i.e., frequency count) of the categories. Interestingly, this continuum also captures the extent to which the approach is tied directly to a research design. For example, constant comparison analysis (Glaser, 1965) is the analysis of choice for the Glaserian version of grounded theory research (Glaser \& Strauss, 1967). In contrast, word count is not linked directly to any qualitative research tradition. 
Figure 2. Qualitative analysis continuum

Note. Adapted from "Toward a new era for conducting mixed analyses: The role of quantitative dominant and qualitative dominant crossover mixed analyses," by A. J. Onwuegbuzie, N. L. Leech, and K. M. T. Collins, 2011, in M. Williams \& W. P. Vogt (Eds.), The Sage handbook of innovation in social research methods, p. 358. Copyright 2011 by Sage Publications.

\subsection{Quantitative Analysis Continuum}

Figure 3 presents what Onwuegbuzie et al. (2011) referred to as the quantitative analysis continuum. In this figure, quantitative analyses are placed on the continuum based on the level of complexity. Consequently, on the left side of the continuum are descriptive statistics techniques that are not associated with any statistical modeling assumptions. Moving towards the right of the continuum, the next class of analyses represents exploratory analyses such as exploratory factor analysis, cluster analysis, correspondence analysis, and multidimensional scaling. These analyses are exploratory in nature because they do not involve null hypotheses statistical significant testing (i.e., no $p$ values are involved). The remaining classes of quantitative analyses on the continuum represent inferential analyses that are governed by statistical modeling assumptions (i.e., distributional assumptions, structural assumptions, and cross-variation assumptions). Building on Onwuegbuzie et al.'s (2011) typology, Ross and Onwuegbuzie (2014) categorized the array of established quantitative analysis techniques into eight levels of complexity (cf. Figure 4). 


\section{Non-Modeling \\ Assumptions}

(e.g., population assumptions,

sampling

assumptions)

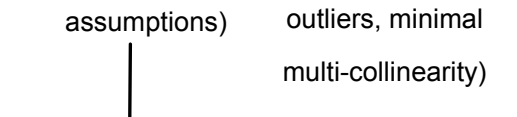

(e.g., absence of

outliers, minimal

multi-collinearity)

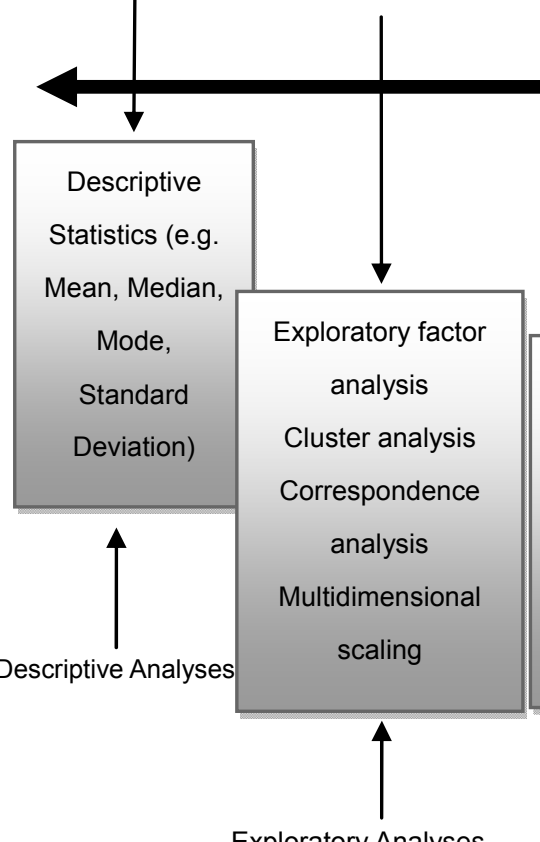

Exploratory Analyses

\section{Modeling Assumptions}

(e.g., distributional assumptions, general linear model assumptions,

structural assumptions, cross-variation assumptions)

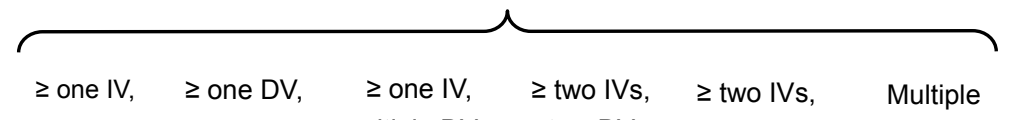

one DV, one IV, multiple DVs, $\geq$ two DVs, $\geq$ two DVs, bi-directional

one level $\geq$ two levels one level one level $\geq$ two levels DVs and IVs

Figure 3. Quantitative analysis continuum

Note. Adapted from "Toward a new era for conducting mixed analyses: The role of quantitative dominant and qualitative dominant crossover mixed analyses," by A. J. Onwuegbuzie, N. L. Leech, and K. M. T. Collins, 2011, in M. Williams \& W. P. Vogt (Eds.), The Sage handbook of innovation in social research methods, p. 359. Copyright 2011 by Sage Publications. 


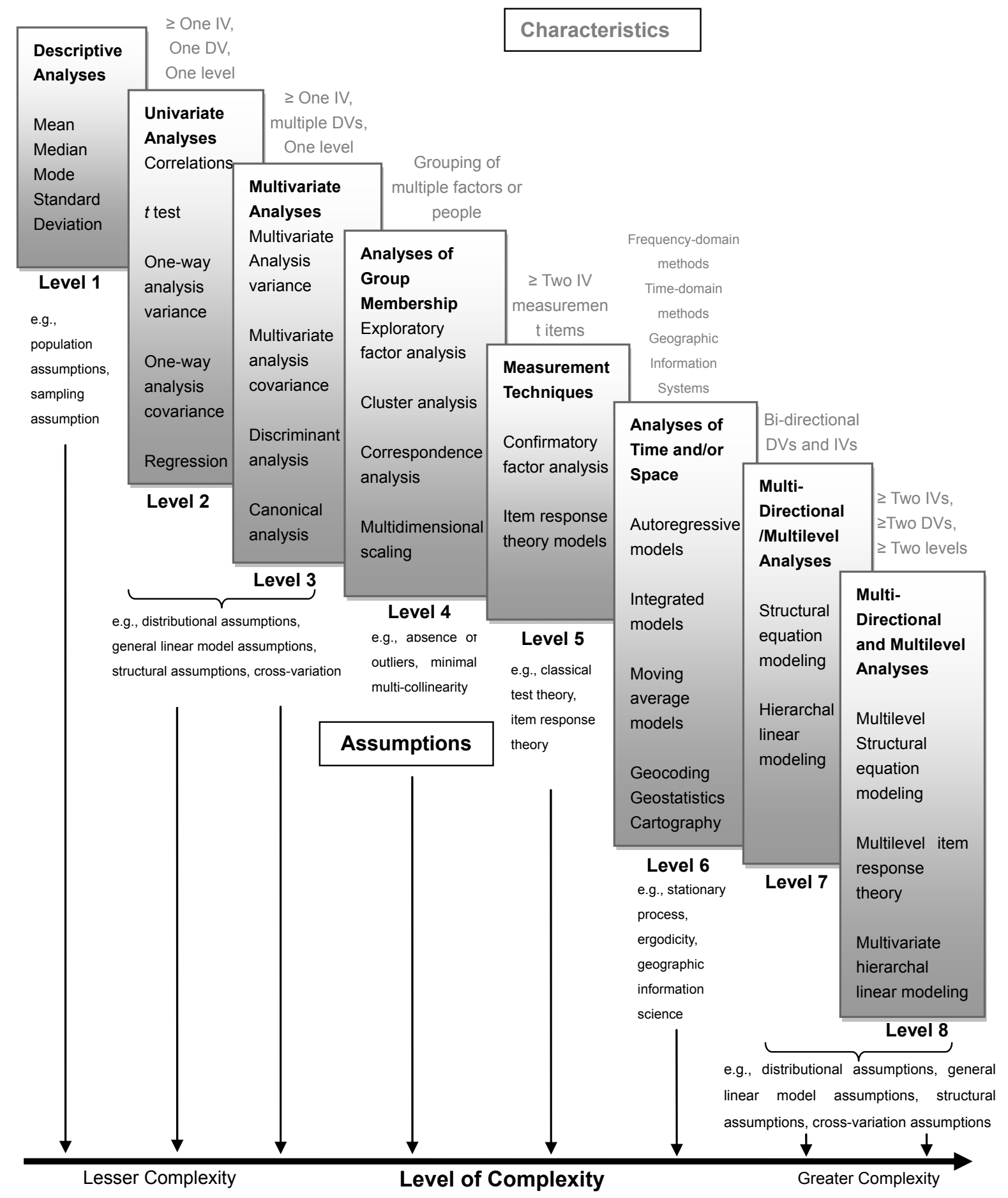

Figure 4. Quantitative analysis complexity continuum

Note. Adapted from "A typology of quantitative analyses," by A. Ross and A. J. Onwuegbuzie, 2014. Copyright 2014 by A. Ross and A. J. Onwuegbuzie.

However, to date, when conducting mixed analyses in general and crossover mixed analyses 
in particular, mixed researchers have not taken full advantage of the range of complexity available - tending to utilize lower levels of quantitative analysis complexity, when used alongside qualitative procedures. Consistent with this assertion. Ross and Onwuegbuzie (2014), who examined the complexity of quantitative analyses, within mixed research approaches, utilized in a flagship mathematics education publication (i.e., Journal for Research in Mathematics Education) over a 5-year period, documented that the mixed researchers used only the lowest three levels of the quantitative analysis continuum (cf. Figure 4) - with virtually all the studies involving the use of either descriptive analyses or univariate analyses (i.e., Levels 1-2), which supports Bazeley's (2010) observation that "there are surprisingly few published studies reporting results from projects which make more than very elementary use of the capacity to integrate data and analyses using computers" (p. 434). With this gap in the literature in mind, the purpose of this article is to introduce the concept of multivariate mixed analyses, which represents a complex form of both non-crossover and crossover mixed analyses.

\section{Conceptual Framework}

Multivariate mixed analyses represent a class of mixed analyses wherein at least one of the quantitative analyses and at least one of the qualitative analyses both involve the simultaneous analysis of multiple variables. These analyses can be conducted in a non-crossover manner whereby the selected complex qualitative analysis is used to analyze the qualitative data and a complex quantitative analysis is used to analyze the quantitative data. Alternatively, and representing an even more advanced form of mixed analysis, multivariate mixed analysis can be conducted in a crossover manner whereby qualitative data are analyzed utilizing a complex quantitative analysis and quantitative data are analyzed using a qualitative analysis in which multiple variables are analyzed simultaneously. For the purpose of this article, an exemplar of a crossover multivariate mixed analysis will be provided.

\section{Heuristic Example}

Setting the Scene: The example of a crossover multivariate mixed analysis involves an embedded mixed research study in which the purpose was to examine the relationship between the statistics anxiety and coping strategies among graduate students enrolled in quantitative-based research methods courses. The quantitative phase involved 115 graduate students from various education disciplines (e.g., special education, elementary education, secondary education, educational administration) who were enrolled in six sections of a quantitative-based educational research course at a mid-southern university. These participants were administered the Statistical Anxiety Rating Scale (STARS) and the Coping Strategies Inventory for Statistics (CSIS). The STARS (Cruise \& Wilkins, 1980), which is a 51-item, 5-point Likert-format instrument assessing statistics anxiety in a wide variety of academic situations, has six subscales: (a) worth of statistics, (b) interpretation anxiety, (c) test and class anxiety, (d) computational self-concept, (e) fear of asking for help, and (f) fear of the statistics instructor. For the present study, the reliability of the STARS subscale scores, as measured by coefficient alpha, was as follows: worth of statistics $(.95 ; 95 \%$ confidence 
interval $[\mathrm{CI}]=.94, .96)$, interpretation anxiety $(.91 ; 95 \% \mathrm{CI}=.87, .93)$, test and class anxiety $(.90 ; 95 \% \mathrm{CI}=.88, .93)$, computational self-concept $(.91 ; 95 \% \mathrm{CI}=.87, .93)$, fear of asking for help $(.89 ; 95 \% \mathrm{CI}=.85, .92)$, and fear of the statistics instructor $(.80 ; 95 \% \mathrm{CI}=.74, .85)$. The CSIS (Jarrell \& Burry, 1989) is a 40-item, 10-point Likert-format instrument that assesses non-facilitative study coping strategies and examination-taking strategies of students enrolled in quantitative-based courses (e.g., statistics). This instrument comprises two scales that evaluate study coping strategies and examination-taking coping strategies. For the present study, the study coping strategies subscale and the examination-taking coping subscale generated scores that had a classical theory alpha reliability coefficient of .77 (95\% $\mathrm{CI}=.70, .83)$ and $.82(95 \% \mathrm{CI}=.77, .86)$, respectively.

The embedded mixed research phase comprised 18 students selected via convenience sampling (Onwuegbuzie \& Leech, 2005), who represented three cohorts of a doctorate of education program at a university located in the southern United States, who had taken a doctoral-level statistics course within the past 6 months at the time of the study. These students were interviewed via three focus groups to ascertain the role that coping strategies played in the context of learning statistics.

\section{Method}

The multivariate analysis conducted to analyze the quantitative phase was a canonical correlation analysis (Cliff \& Krus, 1976; Darlington, Weinberg, \& Walberg, 1973; Onwuegbuzie \& Daniel, 2003; Thompson, 1980, 1984, 1988). This analysis was used to identify a combination of coping strategy dimensions that might predict a combination of statistics anxiety dimensions. The multivariate analysis conducted to analyze the qualitative phase was qualitative comparative analysis (Ragin, 1987), which is a case-oriented qualitative data analysis approach that involves a systematic analysis of similarities and differences across cases of interest. Qualitative comparative analysis facilitates theory-building by allowing the analyst to examine links among multiple themes or variables that have been previously identified by the analyst or by another researcher, as well as by testing and developing the themes/variables to a greater extent.

\section{Results}

\subsection{Quantitative Phase}

The canonical correlation analysis revealed that the two canonical correlations when combined were statistically significant $(F[12,214]=p<.0001)$. However, when the first canonical root was excluded, the remaining canonical root was statistically non-significant. Together, these results suggested that the first canonical function was both statistically significant and practically significant, with the first canonical correlation $\left(R_{c 1}=.60\right)$ contributing $35.9 \%$ (i.e., $R_{c l}{ }^{2}$ ) to the shared variance (Cohen, 1988). However, the second canonical correlation was not statistically significant. Consequently, only the first canonical correlation was interpreted.

Table 5 displays the canonical solution for the first function. Using a cutoff correlation of 0.3 (Lambert \& Durand, 1975), an examination of the standardized canonical function 
coefficients revealed that examination-taking coping strategies (-1.09) made a very important contribution to the set of statistics anxiety variables, with study coping strategies playing a small role (0.15). With respect to the statistics anxiety variable set, interpretation anxiety made a substantial contribution; with the remaining variables making a small contribution. The structure coefficients pertaining to the first canonical function revealed that both examination-taking coping strategies and study coping strategies made important contributions to the set of statistics anxiety variables, with examination-taking coping strategies again playing the biggest role. The square of the structure coefficient indicated that these variables explained $98.9 \%$ and $29.2 \%$ of the variance, respectively. With regard to the statistics anxiety variable cluster, all six variables made an important contribution, with, again, interpretation anxiety making the greatest contribution, explaining $34.8 \%$ of the variance.

Table 5. Canonical solution for first function: relationship between coping strategies dimension scores and statistics anxiety dimension scores

\begin{tabular}{|c|c|c|c|}
\hline Variable & $\begin{array}{l}\text { Standardized } \\
\text { Coefficient }\end{array}$ & $\begin{array}{l}\text { Structure } \\
\text { Coefficient }\end{array}$ & $\begin{array}{l}\text { Structure } \\
\text { Coefficient }^{2}(\%)\end{array}$ \\
\hline \multicolumn{4}{|l|}{ Coping Strategy Dimension: } \\
\hline Examination-taking Coping Strategies & $-1.09^{*}$ & $-0.99^{*}$ & 98.01 \\
\hline Study Coping Strategies & 0.15 & $-0.54^{*}$ & 29.16 \\
\hline \multicolumn{4}{|l|}{ Statistics Anxiety Dimension: } \\
\hline Worth of Statistics & 0.22 & $0.41^{*}$ & 16.81 \\
\hline Interpretation Anxiety & $0.83^{*}$ & $0.59^{*}$ & 34.81 \\
\hline Test and Class Anxiety & 0.01 & $0.46^{*}$ & 21.16 \\
\hline Computational Self-Concept & 0.04 & $0.42^{*}$ & 17.64 \\
\hline Fear of Asking for Help & 0.04 & $0.37^{*}$ & 13.69 \\
\hline Fear of the Statistics Instructors & -0.03 & $0.30^{*}$ & 9.00 \\
\hline
\end{tabular}

Note. ${ }^{*}$ Coefficients with effect sizes larger than .3 (Lambert \& Durand, 1975).

Comparing the standardized and structure coefficients identified some multicollinearity involving study coping strategies of the coping strategy set of variables and worth of statistics, test and class anxiety, computational self-concept, fear of asking for help, and fear of the statistics instructors of the statistics anxiety set of variables because for each of these variables, the standardized coefficient associated with the variable was small, whereas the corresponding structure coefficient was relatively large (Onwuegbuzie \& Daniel, 2003; Tabachnick \& Fidell, 2007).

Overall, the quantitative findings indicated a multivariate relationship between coping 
strategies and statistics anxiety. Examination-taking coping strategies represented a much more important predictor of statistics anxiety than did study coping strategies. However, study coping strategies also played a role in the canonical correlation function, albeit a smaller one.

\subsection{Qualitative Phase}

With regard to the qualitative phase, a constant comparison analysis (Glaser, 1965) of the focus group data yielded six themes related to statistics anxiety (i.e., lack of understanding, class anxiety, anxiety due to multiple responsibility, fear of performance expectations, fear based on prior experience, and fear of the professor/asking for help) and five themes related to coping strategies (i.e., peer support; professor support; personal management, organization, routine, and time; class structure and materials provided; and study skills; cf. Table 6). Each coping strategy theme then was quantitized (Tashakkori \& Teddlie, 1998) by assigning a score of " 1 " if the participant provided a response that was categorized under that theme and a score of " 0 " otherwise-yielding an inter-respondent matrix (i.e., Student $\times$ Theme Matrix; cf. Table 7) (Onwuegbuzie, 2003; Onwuegbuzie \& Teddlie, 2003) that consisted only of 0s and $1 \mathrm{~s}$. The statistics anxiety theme was quantitized into one meta-theme by first determining the number of codes assigned to each statistics theme for each participant and then totaling the number of codes assigned across the six statistics themes. This total then was converted to a " 1 " if it was above the median total and a " 0 " if it was below the median.

Table 6. Description of emergent themes for coping strategies used in statistics course

\begin{tabular}{|l|l|l|}
\hline Theme & Description & Significant Statement Examples \\
\hline Peer support & $\begin{array}{l}\text { Asks for and receives help } \\
\text { from other peers and } \\
\text { collaborates with others }\end{array}$ & $\begin{array}{l}\text { "For me, one of the biggest advantages I saw right then was } \\
\text { being in the cohort because you really utilized that cohort, I } \\
\text { could call Aretha, and another student, you emailed all the } \\
\text { time, you really got to work well with everybody." }\end{array}$ \\
\hline Instructor & $\begin{array}{l}\text { Asks for and receives help } \\
\text { from the instructor }\end{array}$ & $\begin{array}{l}\text { "He was very accessible I thought outside of class which was } \\
\text { helpful because as those questions come up, you'd shoot him } \\
\text { an email and within hours or a day you'd have a response." }\end{array}$ \\
\hline Personal & $\begin{array}{l}\text { Manages self with } \\
\text { organizational tools, routines, } \\
\text { and self-care }\end{array}$ & $\begin{array}{l}\text { "Taking notes, that was very stressful. I was so worried that I } \\
\text { wacorder, I didn't panic if I missed something." }\end{array}$ \\
\hline Class structure & $\begin{array}{l}\text { Utilizes the resources } \\
\text { provided in the course }\end{array}$ & $\begin{array}{l}\text { "The way the course was presented is we had an example } \\
\text { paper, we had a step by step routine in how to do it, and um } \\
\text { an assignment page." }\end{array}$ \\
\hline Study skills & $\begin{array}{l}\text { Applies skills such as } \\
\text { listening, correcting errors, }\end{array}$ & $\begin{array}{l}\text { "I would try to go back and see the errors I had made on the } \\
\text { papers, what were those words that weren't supposed to be } \\
\text { used." }\end{array}$ \\
\hline
\end{tabular}


Note. Adapted from "Relationships among attitudes, coping strategies, and achievement in doctoral-level statistics courses: A mixed research study," by J. P. Combs and A. J. Onwuegbuzie, 2012, International Journal of Doctoral Studies, 7, p. 361. Copyright 2012 by the Informing Science Institute.

Table 7. Inter-respondent matrix for lack of statistics anxiety as a function of coping strategies among 18 doctoral students

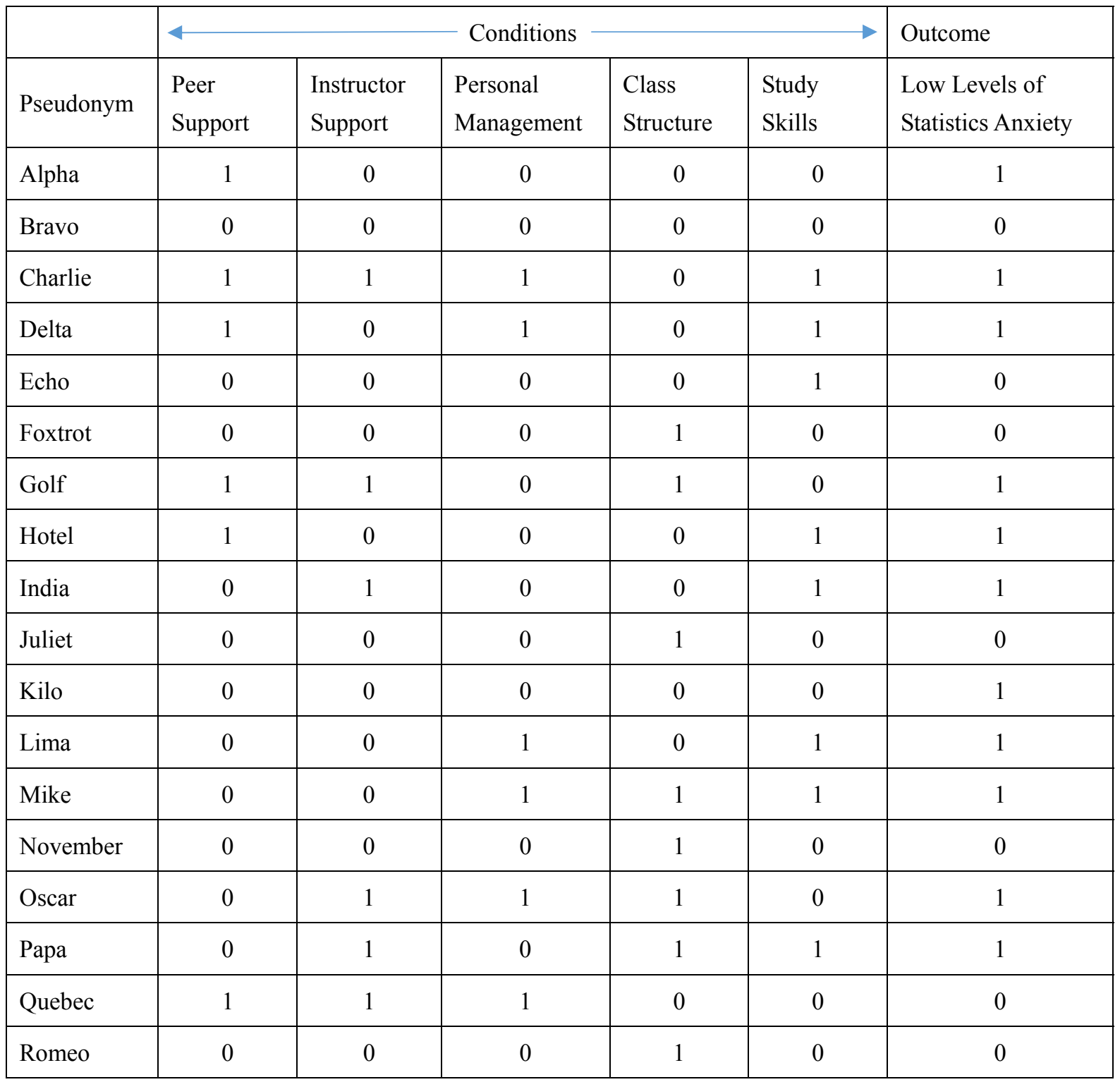

Table 7 then served as what qualitative comparative analysts refer to as a truth table, which, in this case, lists all unique configurations of the 18 study participants and the five emergent coping themes that have been extracted from the data, along with the corresponding outcome (i.e., presence or absence of high levels of statistics anxiety) that have been observed for each configuration (Miethe \& Drass, 1999). This truth table specifies which configurations are 
unique to a category of the construct of interest (i.e., classification variable) and which configurations appear in multiple categories. By comparing the numbers of configurations in these groups, the qualitative comparative analyst is able to estimate the degree that types of outcomes are unique or similar. Next, the researcher "compares the configurations within a group, looking for commonalities that allow configurations to be combined into simpler, yet more abstract, representations" (Miethe \& Drass, 1999, p. 8). This step is conducted by identifying and removing unnecessary variables from these configurations. Specifically, a variable is deemed as unnecessary if its presence or absence within a configuration has no effect on the outcome that is associated with that configuration. The qualitative comparative analyst repeats these comparisons until no further reductions can be made. Next, all redundancies that are identified among the remaining reduced configurations are removed, thereby leading to the final solution, specifically, a statement of the unique characteristics of each category of the typology or theme.

Using the free qualitative comparative software called fsQCA (http://www.u.arizona.edu/ $\sim$ cragin/fsQCA/) to analyze the truth table (i.e., Table 7; standard analyses) revealed a combination of conditions linked to the outcome of high levels of overall statistics anxiety, yielding the following two logical equations:

$$
\begin{gathered}
\mathrm{SA}=(\mathrm{PS})+(\mathrm{IS})+(\mathrm{PM})+(\mathrm{SS}) \\
(\mathrm{PS})+(\mathrm{is})+(\mathrm{PM})+(\mathrm{cs})+(\mathrm{ss})
\end{gathered}
$$

Where,

$\mathrm{SA}=$ low levels of statistics anxiety; PS = peer support; IS = instructor support; $\mathrm{PM}=$ personal management; $\mathrm{CS}=$ class structure; $\mathrm{SS}=$ study skills.

The first solution (i.e., Equation 1) indicates that for low levels of statistics anxiety to occur, peer support, instructor support, personal management, and study skills must be present. The fsQCA software program revealed a consistency score of 1.0 for the first solution, which indicates that this condition did not include any case (i.e., doctoral student) that did not display the outcome (i.e., low levels of statistics anxiety).

The second solution indicates that low levels of statistics anxiety to occur, peer support and personal management must be present regardless of whether instructor support, class structure, and study skills are present. As for the first solution, the consistency score of 1.0 for the second solution indicates that this condition did not include any case (i.e., doctoral student) that did not display the outcome (i.e., low levels of statistics anxiety). Raw coverage measures the proportion of memberships in the outcome explained by each term of the solution. The finding from the fsQCA output that the raw coverage for the first solution (.57) is higher than is the raw coverage (.14) indicates that the first solution covers more cases (i.e., more of the 18 doctoral students) in the data set.

Solution consistency of qualitative comparison analysis indicates the combined consistency of the causal conditions. That is, solution consistency measures the degree to which membership in the solution (the set of solution terms) is a subset of membership in the outcome. The 
fsQCA output revealed a solution consistency of 1.0, which indicates that the membership in the solution (the set of solution terms) is a subset of membership in the outcome (i.e., lack of statistics anxiety). Solution coverage indicates the proportion of membership in the outcome that can be explained by membership in the causal recipes. The fsQCA output revealed a solution coverage of 0.76 , which indicates that most of the doctoral students for which the outcome is present (i.e., low levels of statistics anxiety) are a member of either of the solutions and, thus, are explained by the model. That both the solution consistency and solution coverage are greater than .75 (Ragin, 2008) indicates a correctly specified model. Therefore, in summary, the qualitative comparative analysis of the truth table in Table 7 suggests, in particular, the importance of peer support and personal management in minimizing statistics anxiety.

\section{Meta-Inferences from the Multivariate Mixed Analysis}

The multivariate mixed analysis, which comprised a quantitative multivariate analysis and an embedded multivariate mixed analysis, not only indicated a multivariate relationship between coping strategies and statistics anxiety but also identified the nature of this relationship in terms of the specific coping and anxiety variables involved. If in the quantitative phase, the relationship between a general measure of statistics anxiety and a general measure of coping was examined-via a correlation coefficient (i.e., Level 2 analysis) - then, at best, the conclusion would have been that these two constructs are related to some degree. Although this information would have been useful, by increasing the complexity by just one level (i.e., from Level 2 analysis to Level 3 analysis) via a multivariate analysis (i.e., canonical correlation analysis), a substantially richer understanding of the relationship between statistics anxiety and coping for the underlying sample was obtained. The findings from the quantitative phase of the heuristic example show the (potential) benefit of mixed researchers using more complex quantitative analyses within their mixed analysis frameworks.

Interestingly, even higher levels of quantitative analysis could have been used in this quantitative phase. For example, because other demographic variables (e.g., gender, ethnicity, age), achievement-related variables (e.g., number of statistics courses taken, number of research methodology courses taken, statistics performance), and affective variables (e.g., academic self-concept) also were collected from these 115 graduate students, a structural equation modeling (SEM) analysis (i.e., Level 7 analysis) could have been conducted. For example, this SEM analysis could have been used to test further Combs and Onwuegbuzie's (2012) Expectancy-Value Coping Strategies Model of statistics achievement that they had hypothesized using the frameworks of Eccles and Wigfield (2002) and Ramirez, Emmioglu, and Schau (2010); and they had tested and confirmed using qualitative data (cf. Figure 5). Alternatively, because information also was available regarding the students' place of abode and where their undergraduate institutions were located, a geospatial analysis (i.e., Level 6 analysis) could have been conducted to assess the potential role that location played in students' coping strategies. Such a geospatial analysis could have yielded what Onwuegbuzie (2015) referred to as spatial effect sizes. Alternatively still, a cluster analysis (i.e., Level 4 analysis) could have been conducted to ascertain how the students grouped together with respect their responses to the CSIS. 


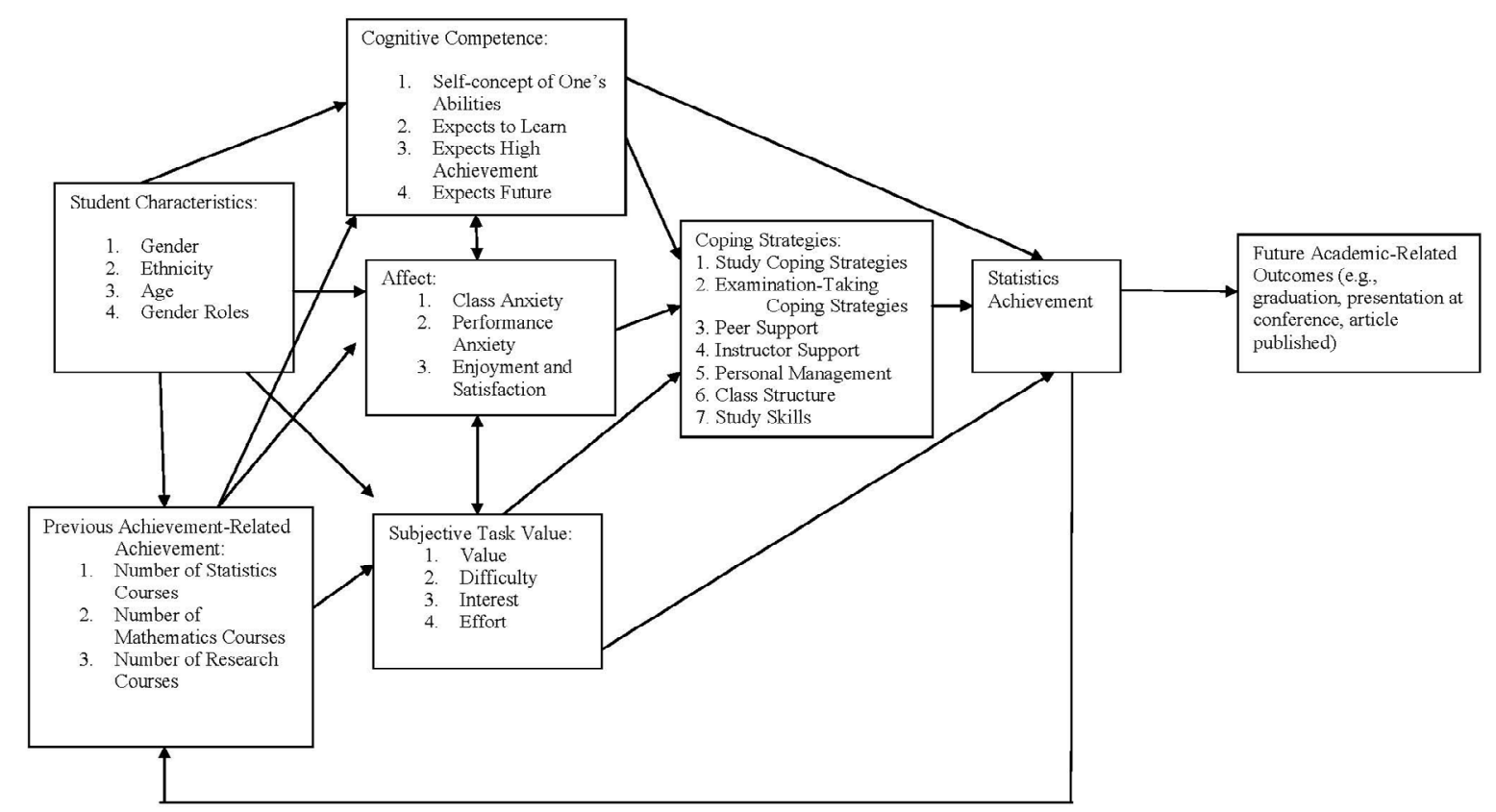

Figure 5. Combs and Onwuegbuzie's (2014) emergent Expectancy-Value Coping Strategies Model of statistics achievement using the frameworks of Eccles and Wigfield (2002) and Ramirez, Emmioglu, and Schau (2010)

Note. Adapted from "Relationships among attitudes, coping strategies, and achievement in doctoral-level statistics courses: A mixed research study," by J. P. Combs and A. J. Onwuegbuzie, 2012, International Journal of Doctoral Studies, 7, p. 364. Copyright 2012 by the Informing Science Institute.

The point here is that conducting a higher level of quantitative analysis enables mixed researchers to get more out of their data, thereby enhancing meta-inference quality. In other words, conducting higher levels of quantitative analyses allows mixed researchers to ask increasingly complex questions within a mixed analysis framework. Unfortunately, the vast majority of researchers do not appear to use multivariate statistical analyses in their mixed research studies (Onwuegbuzie \& Corrigan, 2016; Ross \& Onwuegbuzie, 2014).

With regard to qualitative analyses, our multivariate mixed analysis example has shown not only the utility of using multiple qualitative analysis approaches - as advocated by Leech and Onwuegbuzie (2007) - but also the benefit of using a qualitative analysis (i.e., qualitative comparative analysis) that allows the simultaneous analysis of multiple categories (e.g., sub-themes, themes, meta-themes) - yielding what I am terming a multivariate qualitative analysis. In the current example, an analysis that involved the strong use of a qualitative analysis approach (i.e., constant comparison analysis) was followed up with an analysis that involved the strong use of both quantitative analysis and qualitative analysis approaches (i.e., qualitative comparative analysis). Moreover, this follow-up qualitative analysis led to a crossover analysis in which the emergent themes (cf. Table 6) were quantitized (cf. Table 7) and then subjected to a qualitative comparative analysis. 
Greene, Caracelli, and Graham (1989) conceptualized five purposes for mixing or combining quantitative and qualitative data, which, in essence, provide a purpose for mixing or combining quantitative and qualitative data analysis approaches, as follows:

(a) triangulation (i.e., compare findings from the qualitative data with the quantitative results), (b) complementarity (i.e., seek elaboration, illustration, enhancement, and clarification of the findings from one analytical strand [e.g., qualitative] with results from the other analytical strand [e.g., quantitative]), (c) development (i.e., use the results from one analytical strand to help inform the other analytical strand), (d) initiation (i.e., discover paradoxes and contradictions that emerge when findings from the two analytical strands are compared that might lead to a re-framing of the research question), and (e) expansion (i.e., expand breadth and range of a study by using multiple analytical strands for different study phases). In this multivariate mixed analysis example, the findings from both the multivariate quantitative analysis (i.e., canonical correlation analysis) and multivariate qualitative analysis (i.e., qualitative comparative analysis) provided triangulation inasmuch as they both revealed a multivariate relationship between statistics anxiety and coping strategies. Further, findings from both phases of the multivariate mixed analysis yielded complementarity by revealing different coping strategies that were related to statistics anxiety. Finally, the use of multiple qualitative analysis approaches represented development. As such, the multivariate mixed analysis facilitated the coming to fruition of three of Greene et al.'s (1989) five purposes - thereby facilitating quality meta-inferences.

\section{Conclusions}

The notion of multivariate mixed analyses has not been described in any published work, thereby providing compelling evidence of the significance and innovation of the article. Some mixed researchers might view my call for the conduct of multivariate mixed analyses as representing a paradigm shift. However, I would argue that rather than representing a paradigm shift, this advanced form of mixed analyses represents an extension of existing mixed analysis approaches (see, for e.g., Leech \& Onwuegbuzie, 2010). Thus, I hope that mixed researchers keep in mind this analytical concept (i.e., multivariate mixed analyses) when developing research questions in the future so that they can ask increasingly complex questions that, when answered using multivariate mixed analyses, will help mixed researchers to come closer to verstehen.

\section{References}

Bazeley, P. (2010). Computer assisted integration of mixed methods data sources and analyses. In A. Tashakkori \& C. Teddlie (Eds.), Handbook of mixed methods in social and behavioral research (2nd ed., pp. 431-467). Thousand Oaks, CA: Sage. http://dx.doi.org/10.4135/9781506335193.n18

Cliff, N., \& Krus, D. J. (1976). Interpretation of canonical analyses: Rotated vs. unrotated solutions. Psychometrica, 41, 35-42. http://dx.doi.org/10.1007/BF02291696

Cohen, J. (1988). Statistical power analysis for the behavioral sciences (2nd ed.). Hillsdale, NJ: Lawrence Erlbaum. 
Combs, J. P., \& Onwuegbuzie, A. J. (2012). Relationships among attitudes, coping strategies, and achievement in doctoral-level statistics courses: A mixed research study. International Journal of Doctoral Studies, 7, 349-375. Retrieved from http://ijds.org/Volume7/IJDSv7p349-375Combs0388.pdf

Cruise, R. J., \& Wilkins, E. M. (1980). STARS: Statistical Anxiety Rating Scale. Unpublished manuscript, Andrews University, Berrien Springs, MI.

Darlington, R. B., Weinberg, S. L., \& Walberg, H. J. (1973). Canonical variate analysis and related techniques. Review of Educational Research, 43, 433-454. http://dx.doi.org/10.3102/ 00346543043004433

Eccles, J. S., \& Wigfield, A. (2002). Motivational beliefs, values, and goals. Annual Review of Psychology, 53, 109-132. http://dx.doi.org/10.1146/annurev.psych.53.100901.135153

Glaser, B. G. (1965). The constant comparative method of qualitative analysis. Social Problems, 12, 436-445. http://dx.doi.org/10.1525/sp.1965.12.4.03a00070

Glaser, B. G., \& Strauss, A. L. (1967). The discovery of grounded theory: Strategies for qualitative research. Chicago, IL: Aldine.

Greene, J. C. (2007). Mixed methods in social inquiry. San Francisco, CA: Jossey-Bass.

Greene, J. C. (2008). Is mixed methods social inquiry a distinctive methodology? Journal of Mixed Methods Research, 2, 7-22. http://dx.doi.org/10.1177/1558689807309969

Greene, J. C., Caracelli, V. J., \& Graham, W. F. (1989). Toward a conceptual framework for mixed-method evaluation designs. Educational Evaluation and Policy Analysis, 11, 255-274. http://dx.doi.org/10.3102/01623737011003255

Jarrell, M. G., \& Burry, J. A. (November, 1989). Coping Strategies Inventory for Statistics. Paper presented at the annual meeting of the Mid-South Educational Research Association, Little Rock, AR.

Lambert, Z. V., \& Durand, R. M. (1975). Some precautions in using canonical analysis. Journal of Market Research, XII, 468-475. http://dx.doi.org/10.2307/3151100

Leech, N. L., \& Onwuegbuzie, A. J. (2007). An array of qualitative data analysis tools: A call for qualitative data analysis triangulation. School Psychology Quarterly, 22, 557-584. http://dx.doi.org/10.1037/1045-3830.22.4.557

Leech, N. L., \& Onwuegbuzie, A. J. (2010). Guidelines for conducting and reporting mixed research in the field of counseling and beyond. Journal of Counseling and Development, 88, 61-69. http://dx.doi.org/10.1002/j.1556-6678.2010.tb00151.x

Miethe, T. D., \& Drass, K. A. (1999). Exploring the social context of instrumental and expressive homicides: An application of qualitative comparative analysis. Journal of Quantitative Criminology, 15, 1-21. http://dx.doi.org/10.1023/A:1007591025837

Miles, M., \& Huberman, A. M. (1994). Qualitative data analysis: An expanded sourcebook 
(2nd ed.). Thousand Oaks, CA: Sage.

Onwuegbuzie, A. J. (2003). Effect sizes in qualitative research: A prolegomenon. Quality \& Quantity: International Journal of Methodology, 37, 393-409. http://dx.doi.org/10.1023/ A:1027379223537

Onwuegbuzie, A. J. (March, 2015). Mixed methodology as a multidisciplinary way of thinking: Toward a framework for integrated research and evaluation. Invited Keynote Address presented at the Mixed Methods International Research Association Caribbean Conference at The University of the West Indies, Mona, Jamaica.

Onwuegbuzie, A. J., \& Combs, J. P. (2010). Emergent data analysis techniques in mixed methods research: A synthesis. In A. Tashakkori \& C. Teddlie (Eds.), Sage Handbook of mixed methods in social and behavioral research (2nd ed., pp. 397-430). Thousand Oaks, CA: Sage. http://dx.doi.org/10.4135/9781506335193.n17

Onwuegbuzie, A. J., \& Corrigan, J. A. (April, 2016). Prevalence of mixed methods research in special education. Paper presented at the annual meeting of the American Educational Research Association, Washington, DC.

Onwuegbuzie, A. J., \& Daniel, L. G. (February 12, 2003). Typology of analytical and interpretational errors in quantitative and qualitative educational research. Current Issues in Education, 6(2). Retrieved from http://cie.asu.edu/ojs/index.php/cieatasu/article/view/1609

Onwuegbuzie, A. J., \& Denham, M. (2014). Qualitative data analysis. In R. Warden (Ed.), Oxford Bibliographies. Oxford, England: Oxford Bibliographies. http://dx.doi.org/10.1093/ obo/9780199756810-0078

Onwuegbuzie, A. J., \& Frels, R. K. (2014). Mapping Miles and Huberman's within-case and cross-case analyses onto the literature review process. Unpublished manuscript, Sam Houston State University, Huntsville, TX.

Onwuegbuzie, A. J., Frels, R. K., \& Hwang, E. (2016). Mapping Saldaňa's coding methods onto 6the literature review process. Journal of Educational Issues, 2, 130-150. http://dx.doi.org/10.5296/jei.v2i1.8931

Onwuegbuzie, A. J., \& Leech, N. L. (2005). The role of sampling in qualitative research. Academic Exchange Quarterly, 9, 280-284.

Onwuegbuzie, A. J., Leech, N. L., \& Collins, K. M. T. (2011). Toward a new era for conducting mixed analyses: The role of quantitative dominant and qualitative dominant crossover mixed analyses. In M. Williams \& W. P. Vogt (Eds.), The Sage handbook of innovation in social research methods (pp. 353-384). Thousand Oaks, CA: Sage. http://dx.doi.org/10.4135/9781446268261.n21

Onwuegbuzie, A. J., \& Teddlie, C. (2003). A framework for analyzing data in mixed methods research. In A. Tashakkori \& C. Teddlie (Eds.), Handbook of mixed methods in social and behavioral research (pp. 351-383). Thousand Oaks, CA: Sage. 
Ragin, C. C. (1987). The comparative method: Moving beyond qualitative and quantitative strategies. Berkeley, CA: University of California Press.

Ragin, C. C. (2008). Redesigning social inquiry: Fuzzy sets and beyond. Chicago, IL: The University of Chicago Press. http://dx.doi.org/10.7208/chicago/9780226702797.001.0001

Ramirez, C., Emmioglu, E., \& Schau, C. (2010). Understanding students' attitudes toward statistics: New perspectives using an expectancy-value model of motivation and the Survey of Attitudes toward Statistics ${ }^{C}$. Section on Statistical Education - Joint Statistical Meetings (pp. 830-837). Retrieved from http://www.evaluationandstatistics.com/JSM2010EVM.pdf

Ross, A., \& Onwuegbuzie, A. J. (2014). Complexity of quantitative analyses used in mixed research articles published in a flagship mathematics education journal. International Journal of Multiple Research Approaches, 8, 63-73. http://dx.doi.org/10.5172/mra.2014.8.1.63

Saldaňa, J. (2012). The coding manual for qualitative researchers (2nd ed.). Thousand Oaks, CA: Sage.

Tabachnick, B. G., \& Fidell, L. S. (2007). Using multivariate statistics (5th ed.). Boston, MA: Allyn \& Bacon.

Tashakkori, A., \& Teddlie, C. (1998). Mixed methodology: Combining qualitative and quantitative approaches. Applied Social Research Methods Series (Vol. 46). Thousand Oaks, CA: Sage.

Teddlie, C., \& Tashakkori, A. (2009). Foundations of mixed methods research: Integrating quantitative and qualitative techniques in the social and behavioral sciences. Thousand Oaks, CA: Sage.

Thompson, B. (April, 1980). Canonical correlation: Recent extensions for modelling educational processes. Paper presented at the annual meeting of the American Educational Research Association, Boston, MA.

Thompson, B. (1984). Canonical correlation analysis: Uses and interpretations (ERIC Document Reproduction Service No. ED199269). Newbury Park, CA: Sage.

Thompson, B. (April, 1988). Canonical correlation analysis: An explanation with comments on correct practice (ERIC Document Reproduction Service No. ED295957). Paper presented at the annual meeting of the American Educational Research Association, New Orleans, LA.

\section{Copyright Disclaimer}

Copyright for this article is retained by the author(s), with first publication rights granted to the journal.

This is an open-access article distributed under the terms and conditions of the Creative Commons Attribution license (http://creativecommons.org/licenses/by/3.0/). 